\title{
Differential Th1/Th2 cytokine patterns in chronic arthritis: interferon $\gamma$ is highly expressed in synovium of rheumatoid arthritis compared with seronegative spondyloarthropathies
}

Juan D Cañete, Susana E Martínez, Jaume Farrés, Raimon Sanmartí, Maite Blay, Antoni Gómez, Georgina Salvador, José Muñoz-Gómez

\begin{abstract}
Objective-To investigate possible differences in Th1 and Th2 cytokine mRNA expression in the synovial tissue (ST) of patients with rheumatoid arthritis (RA) and seronegative spondyloarthropathies (SpA) with diagnostic and/or pathogenic interest.

Methods-Eleven RA patients and $14 \mathrm{SpA}$ patients (10 with undifferentiated spondyloarthropathy (USpA), two with ankylosing spondylitis (AS) and two with psoriatic arthritis (PsA)) were included. Th1 (interferon $\gamma$, interleukin 2) and Th2 (interleukin 4, interleukin 5 and interleukin 10) cytokine mRNA levels from arthritic knee ST were quantified by using an optimised polymerase chain reaction method with a computerised analysis system. Protein levels of proinflammatory cytokines (interleukin 1, tumour necrosis factor $\alpha$ and interleukin 6) in synovial fluid were quantified with a specific ELISA test.
\end{abstract}

Results-Th1 cytokines were detected in all of RA ST samples in contrast with $58 \%$ (interferon $\gamma$ ) and $71 \%$ (interleukin 2) of SpA samples. Th2 cytokines were expressed in $90 \%$ of RA ST samples, but the findings in SpA were interleukin 10 in $90 \%$, interleukin 4 in $60 \%$ and interleukin 5 in $40 \%$ of ST samples. However, when the mRNA levels of each cytokine were quantified and corrected for $T$ cell mRNA levels, only interferon $\gamma$ levels were significantly higher in RA than in $\mathrm{SpA}(\mathbf{p}<\mathbf{0 . 0 0 3})$. Thus, the Th1/Th2 cytokine ratio in $R A$ was fivefold that of SpA. Synovial fluid interleukin $1 \beta$ concentrations were higher in RA than in SpA $(p<0.05)$; there were also higher synovial fluid levels of tumour necrosis factor $\alpha$ in RA than in SpA, but without statistical significance.

Conclusion-This study has detected both Th1 and Th2 cytokine gene expression in ST from RA and SpA patients. Synovium interferon $\gamma$ mRNA levels and SF interleukin $1 \beta$ protein levels were significantly higher in RA than in SpA, so reflecting the known proinflammatory activity of interferon $\gamma$ through macrophage activation. Thus, the Th1 (interferon $\gamma$ )/Th2 (interleukin 4) ratio is significantly higher in RA than in SpA ST. These data confirm previous studies on $S T$ Th1/Th2 balance in RA and extend previous work in compar- ing ST RA with subgroups of SpA distinct of $\operatorname{ReA}$.

(Ann Rheum Dis 2000;59:263-268)

Rheumatoid arthritis (RA) and the so called seronegative spondyloarthropathies $(\mathrm{SpA})^{1}$ (including the subgroups of ankylosing spondylitis (AS), reactive arthritis (ReA), undifferentiated spondyloarthropathies (USpA) and psoriatic arthritis (PsA)) are both characterised by chronic synovial inflammation. In these rheumatisms a similar synovial pathology is observed: the synovium is infiltrated by $\mathrm{T}$ cells, plasma cells and macrophages, although some distinguishing immunohistological features have been suggested. ${ }^{2}$

Multiple studies showed that macrophage derived cytokines (interleukin 1 (IL1), tumour necrosis factor $\alpha(\mathrm{TNF} \alpha)$, interleukin 6 (IL6) and interleukin 8 (IL8)) are powerful local protein mediators of major importance in inflammation and joint destruction in RA. ${ }^{34}$ This knowledge has recently led to successful clinical therapeutic trials with anti-cytokines. ${ }^{56}$ However, it has proved difficult to find $\mathrm{T}$ cell derived cytokines, such as interferon $\gamma(\mathrm{IFN} \gamma)$, interleukin 2 (IL2) or interleukin 4 (IL4), in RA synovium, ${ }^{7-9}$ although the relevance of $\mathrm{T}$ cells in the pathogenesis of RA and SpA has been demonstrated in experimental animal models. $^{1011}$

T helper (Th) cells are divided into two subsets based on their cytokine production profiles: Th1 cells mainly secrete IFN $\gamma$ and IL2, whereas Th2 cells generally produce IL4, IL5 and IL10. Studies using animal models indicate that Th1 cytokines promote the development of autoimmune disorders, whereas the Th2 pattern may attenuate these diseases. ${ }^{12}$ The Th1 and Th2 cytokine balance has attracted great interest as it is hypothesised that the degree of polarisation and heterogeneity of $\mathrm{T}$ cell lymphocytes may be important in the initiation and perpetuation of synovial inflammation..$^{13}$ By using highly sensitive techniques, several investigators have found a preferential activation of Th1 cells in rheumatoid synovium, suggesting that $\mathrm{Th} 1$ rather than Th2 cytokines are involved in the pathogenesis of the disease. ${ }^{15-18}$ However, the rheumatoid synovium is not a rich source of $\mathrm{T}$ cell cytokines, and the $\mathrm{T}$ cell primacy in $\mathrm{RA}$ has
Accepted for publication 10 November 1999 
been questioned on the basis of their hyporesponsiveness in synovium of early and chronic RA. ${ }^{19}$

On the other hand, there are few studies on cytokines in patients with $\mathrm{SpA}$, and most of these are devoted to ReA. ${ }^{17}{ }^{18}{ }^{20-22}$ In a previous work we have shown that serum concentrations of IL6, TNF $\alpha$ and IFN $\gamma$ were lower in AS than in RA patients; even so, IL6 levels correlated with the activity and severity of AS. ${ }^{23}$ Recently, we have also found a similar pattern of macrophage-fibroblast derived cytokine (IL1 $\beta$, IL6, IL8, TNF $\alpha$ and transforming growth factor $\beta$ (TGF $\beta)$ ) gene expression in synovium of patients with RA and SpA. However, it was difficult for us to find synovial expression of $\mathrm{T}$ cell derived cytokines in either disease. ${ }^{24}$

Studies on Th1/Th2 cytokine gene expression comparing $\mathrm{SpA}$ and RA synovial tissue are scarce. In previous reports, a predominant Th2 cytokine profile has been found in synovium of ReA, ${ }^{17}{ }^{18}$ although a recent work with quantitative PCR has not confirmed these findings. ${ }^{25} \mathrm{By}$ immunohistological techniques it has been demonstrated an increased Th1/Th2 cytokine ratio in RA synovium when compared with that of ReA. ${ }^{21}{ }^{22}$ However, there are no studies on the Th1/Th2 cytokine pattern in USpA synovium, one of the most prevalent forms of SpA. ${ }^{26}$ Neither are there any studies on IL5, a Th2 cytokine probably implicated in the stimulation of B cells to produce IgA. ${ }^{27}$

In this study we analysed the mRNA expression of Th1 (IFN $\gamma$, IL2) and Th2 (IL4, IL5 and IL10) cytokines in synovium of RA and SpA (predominantly USpA) patients using an optimised quantitative PCR method, with the aim of detecting differences of pathogenic or diagnostic interest, or both, between the two diseases. The possible correlation between these $\mathrm{T}$ cell derived cytokine patterns in synovium and clinical and biological parameters of disease activity, including the levels of the proinflammatory macrophage derived cytokines (IL1 $\beta$, IL6, TNF $\alpha$ ) in synovial fluid, was also investigated.

\section{Methods}

PATIENTS

A total of 29 patients were included in the study: 12 suffered from RA (1987 ARA criteria); eight of them with positive rheumatoid factor (>30 IU/1, nephelometry). Disease duration was (mean (SD)) 34 (34) months. The remaining 17 patients suffered from SpA, with 46 (68) months of disease duration. Twelve of them had USpA (ESSG criteria) ${ }^{28}$ (eight HLA-B27 positive, by microlymphocytotoxicity test); three had AS (New York criteria, all HLA-B27 positive), and two had psoriatic arthritis with peripheral and axial involvement (both B27 negative). Both RA and SpA patients were outpatients with active disease and knee synovitis. RA patients were not treated with slow acting anti-rheumatic drugs or prednisone in a dose higher than 5 $\mathrm{mg}$ /day during the three months that preceded their inclusion in this study. SpA patients were treated only with non-steroidal antiinflammatory drugs (NSAIDs).
The ethical committee of the Hospital Clinic of Barcelona approved the study.

Blood and synovial tissue samples were obtained at clinical assessment. Clinical peripheral synovitis activity was measured according to Thompson's articular index. ${ }^{29}$ Eight synovial knee tissue samples were obtained from each patient using a needle biopsy (Parker and Pearson). The inflammatory synovitis was confirmed in each case by haematoxylin and eosin staining. The synovial tissue samples were dipped in guanidinium isothiocyanate buffer $^{30}$ and immediately frozen in liquid nitrogen.

RNA ISOLATION FROM SYNOVIAL TISSUE AND QUANTITATIVE REVERSE TRANSCRIPTASE-PCR ANALYSIS

Total RNA was isolated from synovial tissue by the guanidinium isothiocyanate method. ${ }^{30}$ First strand cDNA synthesis was performed using random hexamers as primers and MMLV reverse transcriptase at $42^{\circ} \mathrm{C}$ for 60 minutes. cDNA $(1 \mu \mathrm{l})$ was used in a PCR mixture containing $67 \mathrm{mM}$ TRIS-HCl, $\mathrm{pH} 8.8,16 \mathrm{mM}$ $\left(\mathrm{NH}_{4}\right)_{2} \mathrm{SO}_{4}, 0.01 \%$ Tween $20,1.5 \mathrm{mM} \mathrm{MgCl}$, $0.1 \mathrm{mM}$ of each deoxynucleotide triphosphate, $0.4 \mathrm{mM}$ of either $\beta_{2}$ microglobulin $\left(\beta_{2} \mathrm{M}\right)$, CD3, IFN $\gamma$, IL2, IL4 IL5 or IL10 specific primers (Clontech Laboratories, Palo Alto, CA) and 2.5 U Taq polymerase. Amplification of cDNA sequences was carried out in a PTC100 Programmable Thermal Controller (MJ Research, Watertown, MA). The optimised conditions were 35 cycles of denaturation at $94^{\circ} \mathrm{C}$ for 45 seconds, annealing at $60^{\circ} \mathrm{C}$ for 45 seconds, and extension at $72^{\circ} \mathrm{C}$ for two minutes (except 30 seconds for IL2 and IL5), followed by a final extension step at $72^{\circ} \mathrm{C}$ for eight minutes. Negative controls (without target DNA) were included in each experiment to exclude cross contamination. $\beta_{2} \mathrm{M}$ DNA was used as a positive control for the presence of total mRNA, and CD3 DNA for the presence of $T$ cell mRNA. All samples were analysed in duplicate and yielded similar results; one of the duplicates was further used for quantification.

PCR products were separated by agarose gel electrophoresis and visualised by ethidiumbromide staining. The resulting fluorescent bands were video-digitalised by a GelDoc 1000 UV-Gel camera and quantified by a computerised analysis system using Molecular Analyst, version 1.4 software (Bio-Rad, Richmond, CA). Previously, the identity of each PCR product was confirmed by Southern hybridisation using sequence specific, digoxigenin labelled (Boehringer Mannheim, Germany) positive control cDNA (Clontech).

To permit quantitative PCR, analysis data must be collected in the exponential phase of the amplification reaction. To ensure this, standard curves for each cytokine, as well as $\beta_{2} M$ and CD3, were obtained by plotting the band adjusted volume (counts $\times \mathrm{mm}^{2}$ ) against the log of initial cDNA copy number added to the PCR. Under the optimised PCR conditions, the lower limit of detection was found to be approximately 30 molecules cDNA/ reaction. An example of the PCR products 


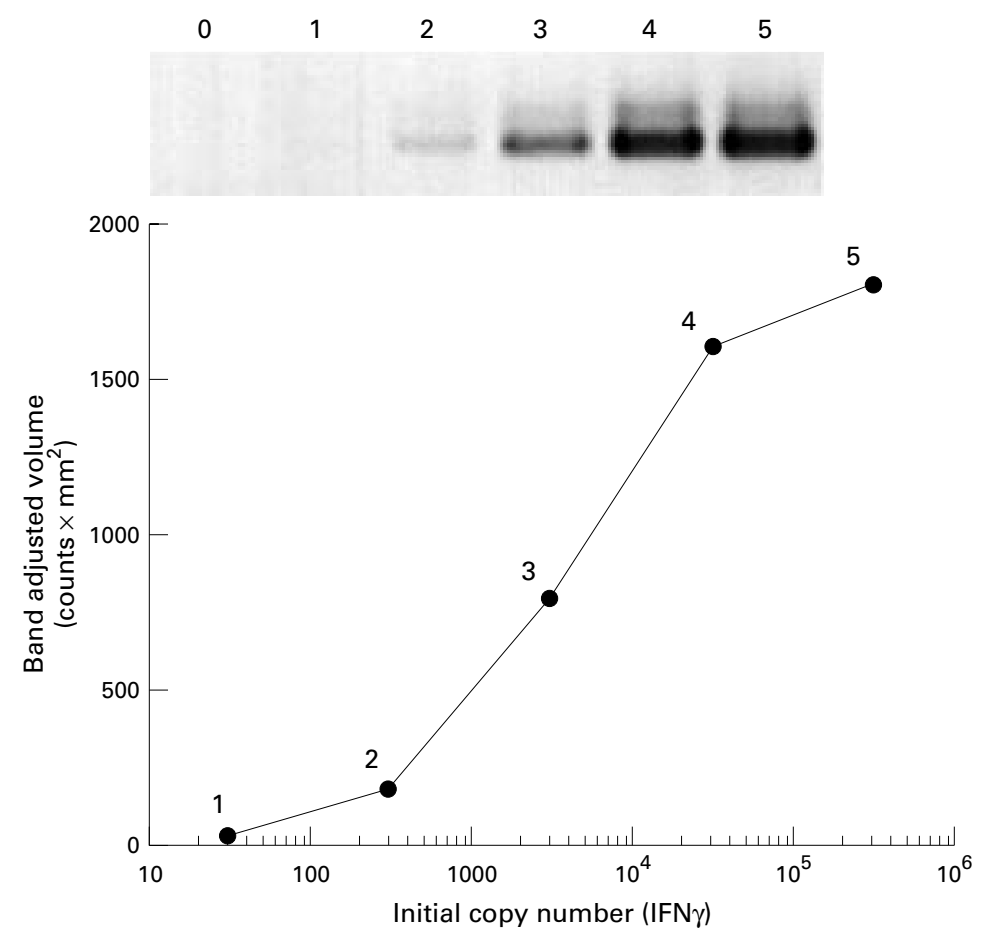

Figure 1 Amplification of 1:10 serial dilutions of positive control IFN $\gamma$ cDNA. Lane 0 is negative control. The band adjusted volume (counts $\times \mathrm{mm}^{2}$ ) was plotted against the log number of target cDNA copies.

obtained from a serial dilution of IFN $\gamma$ and the corresponding standard curve is shown in figure 1 .

MEASUREMENT OF CYTOKINES IN SYNOVIAL FLUID Synovial fluid was frozen at $-70^{\circ} \mathrm{C}$ until assayed. IL $1 \beta$, IL6 and TNF $\alpha$ values were each measured with a specific ELISA test (Medgenix Diagnostics, Brussels, Belgium) in accordance with the manufacturer's instructions. In each assay, the appropriate recombinant human cytokine was used to generate the

Table 1 Demographic, clinical and biological data of the 25 patients finally included in the study

\begin{tabular}{|c|c|c|c|}
\hline & $R A$ & $S p A$ & \\
\hline Number of patients & 11 & 14 & \\
\hline $\operatorname{Sex}(M / F)$ & $6 / 5$ & $9 / 5$ & \\
\hline Age (mean (SD) years) & $47(16)$ & $35(36)$ & NS \\
\hline Disease duration (mean (SD) months) & $36(34)$ & $37(53)$ & NS \\
\hline Thompson index (mean (SD)) & $210(106)$ & $136(62)$ & NS \\
\hline Rheumatoid factor positive (\%) & $8(73)$ & 0 & \\
\hline HLA B-27 positive $(\%)$ & 0 & $10(71)$ & \\
\hline $\mathrm{CRP}$ (mean (SD) mg/dl) & $4.3(5.9)$ & $2.4(3.75)$ & NS \\
\hline Number of cells in synovial fluid (mean (SD) ml) & $8456(6112)$ & $10727(8699)$ & NS \\
\hline
\end{tabular}

RA: rheumatoid arthritis. SpA: seronegative spondyloarthropathies. CRP: C reactive protein.
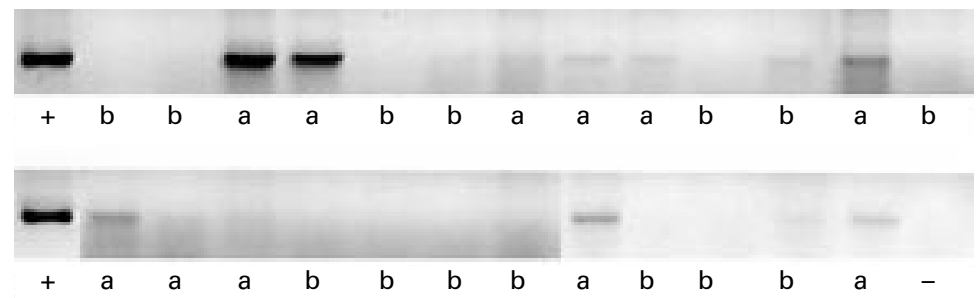

Figure 2 PCR amplification of the IFN $\gamma$ mRNA (427-bp fragment) from the synovium of rheumatoid arthritis $(R A)$ and seronegative spondyloarthropathy $(S p A)$ patients included in this study. Lanes: $a, R A ; b, S p A ;+$, positive control; -, negative control, without added template DNA. standard curve. Sensitivity of the various assays was: IL1 $\beta: 2 \mathrm{pg} / \mathrm{ml}$, IL6: $3 \mathrm{pg} / \mathrm{ml}$ and TNFa: 3 $\mathrm{pg} / \mathrm{ml}$.

STATISTICAL ANALYSIS

The Mann-Whitney $U$ test was used to determine whether there was a significant difference in the level of expression of each cytokine between patients with RA and SpA. Correlation analysis between different cytokines and other clinical and biological parameters was analysed by the nonparametric Spearman test. The level of statistical significance used was $\mathrm{p}<0.05$.

\section{Results}

Four patients (one with RA, two with USpA and one with AS) were excluded from the initial groups because no CD3 mRNA was detected in their synovial samples, although they had $\beta_{2} \mathrm{M}$ mRNA. Table 1 details the clinical, biological and demographic data from the 25 patients who were finally analysed. There were no statistical differences between RA and $\mathrm{SpA}$ regarding age, disease duration, activity of peripheral arthritis (measured by Thompson's articular index), CRP or number of cells in the synovial fluid.

DETECTION AND QUANTIFICATION OF TH1 AND TH2 CYTOKINES MRNA IN SYNOVIUM FROM RA AND SPA PATIENTS

To investigate the $\mathrm{T}$ helper profile of lymphocytes present in RA and SpA synovium, the expression of cytokine mRNAs that are useful in defining Th1 (IL2 and IFN $\gamma$ ) and Th2 (IL4, IL5 and IL10) lymphokine patterns were evaluated. By using a sensitive PCR method with a computer assisted analysis, we were able to detect Th1 and Th2 cytokine mRNAs in the synovium of RA and SpA patients. In general, RA synovium showed greater expression of both Th1 and Th2 cytokine genes than that of SpA: Th1 cytokine mRNAs could be detected in all RA synovium samples, but only in $58 \%$ (IFN $\gamma$, fig 2) and $71 \%$ (IL2) of SpA samples. The mRNAs from IL4 and IL5 were also detected in $90 \%$ of RA samples against $60 \%$ and $40 \%$ of $\mathrm{SpA}$ samples, respectively. However, IL10 was expressed similarly in RA and SpA synovium (90\% of samples).

Quantification of Th1/Th2 cytokine mRNA showed that RA synovium expressed statistically significant higher levels of IFN $\gamma$, IL2 and IL4 than SpA synovium (table 2). The statistical difference remained when the results were expressed relative to the amount for $\beta_{2} M$ mRNA. However, when the results were expressed relative to the amount for CD3 mRNA, which is expressed specifically by $T$ cells, only IFN $\gamma$ levels were higher in RA compared with $\mathrm{SpA}(\mathrm{p}<0.003)$ (fig 3). This result suggests that the differential expression of IFN $\gamma$ between RA and $\mathrm{SpA}$ synovium could not be attributed to a lower density of $T$ cells in SpA synovium biopsy samples compared with that of RA. Production of detectable Th2 cytokine mRNA in RA synovium was not associated with a reduction of Th1 cytokine mRNA. Although both diseases express a 
complex pattern of mRNA cytokines in their synovium, the Th1/Th2 (IFN $\gamma /$ IL4) ratio is fivefold greater in RA than in $\mathrm{SpA}$, thus supporting a predominantly Th1 cytokine pattern in RA in comparison with SpA. No significant differences in the cytokine profile were observed between the different SpA subgroups (data not shown).

In synovium from $\mathrm{SpA}$ patients, but not in RA patients, the expression of IFN $\gamma$ correlated with that of IL2 $(r=0.85 ; \mathrm{p}<0.0001)$, but no other evidence of interdependence between the expression of Th1 or Th2 mRNA was found. No correlation between the synovium cytokine mRNA and clinical and biological data of active disease was observed, except for a positive correlation between IL4 mRNA levels and Thompson's articular index in $\mathrm{SpA}(r=$ $0.59 ; \mathrm{p}=0.04)$.

QUANTIFICATION OF PROINFLAMMATORY

CYTOKINES IN SYNOVIAL FLUID

Synovial fluid levels of macrophage derived cytokines, IL1 $\beta, \mathrm{TNF} \alpha$ and IL6, were each

Table $2 T$ cell cytokine $m R N A$ levels in synovial tissue from rheumatoid arthritis $(R A)$ and seronegative spondyloarthropathy $(S p A)$ patients

\begin{tabular}{|c|c|c|c|}
\hline & $R A(n=11)$ & $S p A(n=14)$ & \\
\hline $\mathrm{IFN} \gamma^{\star}$ & $565(716)$ & $26(40)$ & $<0.0001$ \\
\hline $\mathrm{IFN} / \beta 2 \mathrm{M} \dagger$ & $0.32(0.32)$ & $0.02(0.02)$ & $<0.0001$ \\
\hline IFN / CD $3 \ddagger$ & $0.56(0.66)$ & $0.14(0.28)$ & $<0.003$ \\
\hline IL $2^{\star}$ & $70(109)$ & $18(29)$ & $<0.02$ \\
\hline IL2 / $\beta 2 \mathrm{M} \dagger$ & $0.05(0.05)$ & $0.01(0.02)$ & $<0.015$ \\
\hline IL2 / CD3 & $0.09(0.11)$ & $0.11(0.28)$ & 0.149 (NS) \\
\hline IL4 ${ }^{\star}$ & $103(98)$ & $23(51)$ & $<0.003$ \\
\hline IL4 / $\beta 2 \mathrm{M} \dagger$ & $0.07(0.06)$ & $0.02(0.03)$ & $<0.009$ \\
\hline IL4 / CD $3 \ddagger$ & $0.12(0.12)$ & $0.12(0.30)$ & 0.062 (NS) \\
\hline IL5* & $43(55)$ & $22(41)$ & $<0.06$ (NS) \\
\hline IL5 / $\beta 2 \mathrm{M} \dagger$ & $0.04(0.09)$ & $0.03(0.06)$ & 0.124 (NS) \\
\hline IL5 / CD $3 \ddagger$ & $007(0.14)$ & $0.13(0.31)$ & 0.439 (NS) \\
\hline IL10* & $69.6(507)$ & $398(462)$ & 0.134 (NS) \\
\hline IL10 / $\beta 2 \mathrm{M} \dagger$ & $0.55(0.43)$ & $0.28(0.33)$ & 0.120 (NS) \\
\hline IL10 / CD3 & $1.00(0.86)$ & $0.95(1.08)$ & 0.647 (NS) \\
\hline
\end{tabular}

Data shown as mean (SD). ${ }^{\star}$ Expressed in count $\times \mathrm{mm}^{2}$. $†$ Values corrected for $\beta 2 \mathrm{M}$ mRNA levels. $¥$ Values corrected for $\mathrm{CD} 3$ mRNA levels.

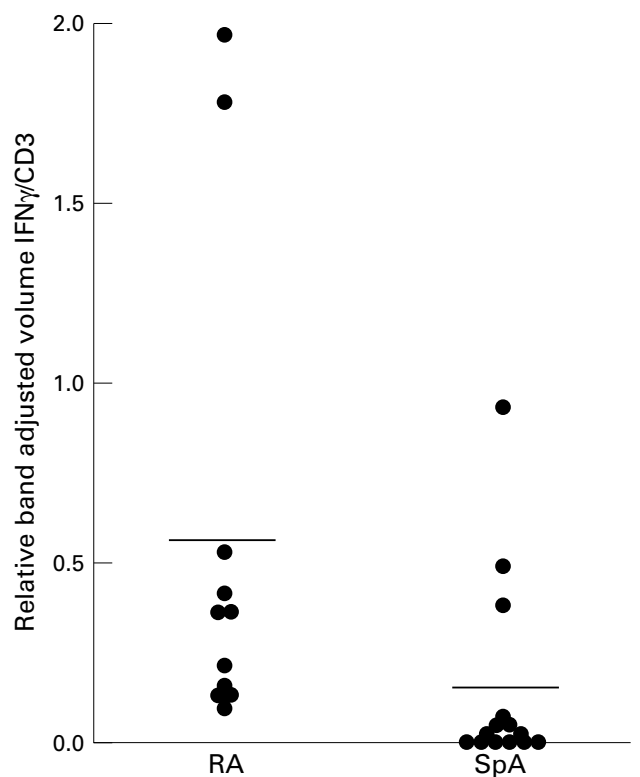

Figure $3 I F N \gamma$ $m R N A$ expression in the synovium of $R A$ and $S p A$ patients. For each patient the $I F N \gamma / C D 3$ ratio is plotted. Arithmetic mean values are indicated by horizontal bars.
Table 3 Synovial fluid levels of monocyte/macrophage derived cytokines ${ }^{\star}$

\begin{tabular}{lccl}
\hline & $R A(n=11)$ & $S p A(n=14)$ & \\
\hline IL6 & $12777(18392)$ & $19003(22543)$ & (NS) \\
IL1 $\beta$ & $22(18)$ & $12(23)$ & $<0.05$ \\
TNF $\alpha$ & $62(57)$ & $31(25)$ & (NS) \\
\hline
\end{tabular}

^Data shown as mean (SD) pg/ml.

measured by specific ELISA tests to find differences between RA and $\mathrm{SpA}$, as these cytokines are major mediators of inflammation and joint destruction. IL1 $\beta$ levels were higher in RA than in SpA ( $\mathrm{p}<0.05)$ (table 3). Moreover, there were also higher levels of TNF $\alpha$ in RA than in SpA, but without statistical significance. Furthermore, in SpA patients, but not in RA patients, a positive correlation was detected between levels of IL6 and TNF $\alpha$ from synovial fluid $(r=0.72 ; \mathrm{p}=0.02)$, and also between IL6 and the number of cells from knee synovial fluid $(r=0.72 ; \mathrm{p}=0.02)$.

\section{Discussion}

In this study the mRNA profile of $\mathrm{T}$ cell derived cytokines expressed in synovium from RA and SpA patients was evaluated by quantitative RT-PCR. In addition, their possible correlation with the protein levels of macrophage derived cytokines in synovial fluid and with clinical and biological data from patients was analysed. Our results show that: (1) in both RA and $\mathrm{SpA}$ synovium a complex pattern of $\mathrm{T}$ cell derived cytokines is observed, with the two diseases expressing Th1 (IFN $\gamma$ and IL2) and Th2 (IL4, IL5 and IL10) cytokines; (2) the expression of Th1 and Th2 (except for IL10) cytokine mRNA was more prevalent in RA than in SpA patients; (3) IFN $\gamma$ mRNA levels were significantly higher in RA than in SpA synovium; (4) the Th1/Th2 (IFN $\gamma /$ IL4) cytokine mRNA ratio was higher (5:1) in RA than in SpA synovium, supporting a predominantly Th1 pattern of cytokine mRNA expression in RA, but a mixed or Th0-like pattern in $\mathrm{SpA}$; (5) IL4 mRNA levels correlated positively with Thompson's articular index in SpA patients; (6) synovial fluid levels of IL1 $\beta$ were significantly higher in RA than in SpA patients.

The data of this study confirm other studies on Th1/Th2 cytokine expression on RA synovium and extend previous works by investigating USpA patients and by determining IL5 expression. We studied mRNA cytokine expression in synovium because in these diseases the synovial joints display the most marked pathology. The PCR method used in this study has been shown to be sensitive and reproducible. $^{31}$ Moreover, it has previously been demonstrated that, in general, the pattern of cytokine gene expression in synovial tissue paralleled the profile of cytokine release in synovial explant supernatant. ${ }^{3233}$

The major finding in this study was a marked difference in IFN $\gamma$ mRNA levels between the two disease groups, with significantly higher levels in RA synovium samples. This was not because of different $T$ cell density between the biopsy specimens analysed as it remained after correcting for the levels of CD3 mRNA, which 
is specific for $\mathrm{T}$ cells. Our results are consistent with previous evidence for a predominance of Th1 cytokine pattern in RA synovium, ${ }^{15-18} 2234$ and with several studies that have also detected the expression of Th2 along with Th1 cytokines in this disease. ${ }^{35} 36$ Moreover, a higher ratio of IFN $\gamma / \mathrm{IL} 4$ positive cells in RA than in ReA has previously been shown using immunohistological techniques. ${ }^{1822}$ In another study, IFN $\gamma$ and its receptor were found to be more abundant in RA synovium than in osteoarthritic synovium, and this has been proposed as an evidence for the role of this cytokine in the pathogenesis of rheumatoid inflammation. ${ }^{37}$ However, a recent study clearly shows the reduced expression of IFN $\gamma$ by T cells from RA synovium when compared with $\mathrm{T}$ cells from tonsils, a chronic $\mathrm{T}$ cell mediated immunological reaction. The hyporesponsiveness state of $T$ cells in RA has been widely reported, although it is not observed in all RA patients. Thus, it has been argued that $T$ cell activity waxes and wanes during the course of RA, or that $\mathrm{T}$ cell activity plays a dominant part in some subsets of the patient population. ${ }^{19}$

A similar expression of $\mathrm{Th} 1$ and $\mathrm{Th} 2$ cytokines was detected in all $\mathrm{SpA}$ patients. However, the low levels of IFN $\gamma$ mRNA in SpA synovium could make the levels of $\mathrm{Th} 2$ cytokines more relevant in controlling disease activity, because of the known mutually inhibitory effect between IFN $\gamma$ and IL4. ${ }^{38}$ Previous studies on cytokines in SpA synovium have not included USpA patients (the most prevalent group in our SpA patients) and they were basically performed with ReA patients. ${ }^{21}$ Conflicting results have been reported regarding a predominance of Th1 or Th2 cytokines in ReA. ${ }^{17} 2539$ Two recent works using immunohistological methods showed a lower amount of IFN $\gamma$ than IL4 expression in ReA synovium. ${ }^{22}{ }^{40}$ Another study using PCR and immunohistochemistry in PsA synovium detected high levels of IFN $\gamma$, IL2 and IL10, but it did not detect IL4. Interestingly, the IFN $\gamma$ levels were greater in PsA than in RA synovium. ${ }^{33}$ However, the full clinical classification of PsA patients was not given. Our study included only two PsA patients with axial and peripheral disease and their cytokine profile was similar to that of USpA and AS patients. The low number of patients with PsA excludes a comparison between the two studies. With respect to IL5, which may be implicated in IgA production by $\mathrm{B}$ cells in $\mathrm{SpA}$, a preliminary study detected IL5 producing cells in RA synovium ${ }^{35}$ but a different work only detected gene expression in one out of five samples of PsA synovium. ${ }^{33}$ Our results do not indicate a differentiated role for IL5 in SpA synovium compared with RA synovium.

An increase in IFN $\gamma$ over IL4 production may be of pathogenic significance and may account for several of the histomorphological changes in RA, such as activation of monocytes/macrophages and upregulation of HLA class II antigens. ${ }^{15}$ Therefore, the Th1 pattern, specifically the higher levels of IFN $\gamma$ in RA synovium, could be responsible for the known progressive and destructive course of this disease, whereas the balanced expression of Th1 and Th2 cytokines in SpA synovium could be related to the frequently observed non-aggressive inflammation in these diseases. Recently, it has been observed that in RA patients, both a decrease in IFN $\gamma$ and an increase in IL4 production by peripheral $\mathrm{T}$ cells correlated with disease activity and severity. ${ }^{41}$ The same work suggests that these phenomena probably reflect selective Th1 cell migration into the joint, and points to a role for the Th1/Th2 balance in RA pathogenesis.

We have found increased levels of IL10 gene expression in both RA and SpA synovium. Although the synthesis of IL10 is not restricted to Th2 cells, this cytokine has an important immunoregulatory role in arthritis through inhibition of machrophage derived cytokines. Previous studies have detected high levels of IL10 in joints of RA patients, although these levels are insufficient to control the immunoinflammatory response. ${ }^{42}$ The arthritic joints of ReA patients have characteristically high IL10 and IL4, and low IFN $\gamma$ levels, and this balance has been related with the persistence of bacteria in the joint. ${ }^{43}$

Also of interest in our study are the higher levels of proinflammatory cytokines in synovial fluid from patients with RA in comparison with $\mathrm{SpA}$, as IL1 $\beta$ and TNF $\alpha$ are the most important macrophage derived cytokines that contribute to the pathogenesis of RA. The known effect of IFN $\gamma$ is to activate macrophages, which produces high levels of proinflammatory cytokines. ${ }^{44}$ In this respect, the higher levels of IFN $\gamma$ in RA synovium may account for the significantly higher levels of IL1 $\beta$ in synovial fluid from RA patients. The correlation between TNF $\alpha$, IL6 levels and the number of synovial fluid cells is consistent with our knowledge of the inflammatory cascade, where $\mathrm{TNF} \alpha$ induces production of IL6, and both cytokines produce chemoattracting factors, which cause cellular infiltration of the joint space.

Probably because of the sample size, there are no other statistical significant correlations in the RA group. However, in SpA patients the positive correlation between IL4 mRNA levels in synovium and the activity of peripheral synovitis, measured by Thompson's articular index, is remarkable. In this respect it has been demonstrated that IL4 may contribute to the pathogenesis of synovitis by different mechanisms. ${ }^{43} 45$

In conclusion, our study detects significant differences in IFN $\gamma$ mRNA levels between RA and SpA (mostly USpA patients) synovium, as well as higher IL1 $\beta$ protein levels in RA synovial fluid. Moreover, the IFN $\gamma / \mathrm{IL} 4 \mathrm{mRNA}$ ratio is significantly higher in the synovial tissue of RA than that of $\mathrm{SpA}$ patients. These data confirm previous work on Th1/Th2 cytokine balance in RA and extend the results by comparing RA to $\mathrm{SpA}$ subgroups distinct of ReA, predominantly USpA, and probably reflect differences in the pathogenesis of synovitis between RA and $\mathrm{SpA}$, as well as between different subgroups of SpA. 
The authors are grateful to Dr Salvador Bartolomé, from the Laboratory of Electrophoretic, Fluorescent and ChemiluminesBiology, Universitat Autònoma de Barcelona, for his technical assistance.

Funding: this study was supported in part by a grant from DGICYT (Ministerio de Sanidad) Project PM91-0042, and from CYT (Ministerio de Sanidad) Project
the Hospital Clínic de Barcelona. Spain.

1 Khan MA. An overview of clinical spectrum of heterogeneity of spondyloarthropathies. Rheum Dis Clin North Am ity of spondyloar

2 Cunnane G, Bresnihan B, FitzGerald O. Immunohistologic analysis of peripheral joint disease in Ankylosing spondylitis. Arthritis Rheum 1998;41:180-2.

3 Unemori EN, Amento EP. Role of cytokines in rheumatoid arthritis. In: Aggarwall BB, Puri RK, eds. Human cytokines: their role in disease and therapy. Boston. Blackwell Science 1995:217-36.

4 Brennan FM, Maini RN, Feldmann. Role of proinflammatory cytokines in rheumatoid arthritis. Springer Semin Immunopathol 1998;20:133-47.

5 Elliot MJ, Maini RN, Feldmann M; Kalden JR, Antoni C, Smolen JS, et al. Randomised double-blind comparison of chimeric monoclonal antibody to tumour necrosis factor alpha (cA2) versus placebo in rheumatoid arthritis. Lancet 1994;344:1105-10.

6 Moreland LW, Baumgartner SW, Schiff MH, Tindall EA, Fleischmann RM, Weaver AL, et al. Treatment of rheumatoid arthritis with a recombinant human tumour necrosis factor receptor (p75)-Fc fusion protein. N Engl J Med factor receptor
1997;337:141-7.

7 Firestein GS, Alvaro-Gracia JM, Maki R. Quantitative anaylisis of cytokine gene expression in rheumatoid arthrianaylisis of cytokine gene expressio
tis. J Immunol 1990;144:3347-53.

8 Chen E, Keystone EC, Fisch EN. Restricted cytokine expression in rheumatoid arthritis. Arthritis Rheum 1993;35:901-10.

9 Miossec P, Naviliat M, Dupuy A, Sany J, Banchereau J. Low levels of interleukin-4 and high levels of transforming growth factor- $\beta$ in rheumatoid synovitis. Arthritis Rheum 1990;33:1180-7.

10 Mima T, Saeki J, Ohshima S, Nishimoto N, Matsushita M, Shimizu $M$, et al. Transfer of rheumatoid arthritis into severe combined immunodeficient mice. The pathogenetic implications of $\mathrm{T}$ cell populations oligoclonally expanding in the rheumatoid joints. J Clin Invest 1995;96: 1746-58.

11 Breban M, Hammer RE, Richardson JA, Taurog JD. Transfer of the inflammatory disease of HLA-B27 transgenic rats fer of the inflammatory disease of HLA-B27 transgenic rats
by bone marrow engrafment. J Exp Med 1993;178:160716 .

12 Abbas AK, Murphy KM, Sher A. Functional diversity of helper T lymphocytes. Nature 1996;383:787-93.

13 Miossec P, van der Berg W. Th1/Th2 cytokine balance in arthritis. Arthritis Rheum 1997;40:2105-15.

14 Kamradt T, Burmester G-R. Cytokines and arthritis: Is the Th1/Th2 paradigm useful for understanding pathogenesis? J Rheumatol 1998;25:6-7

15 Dolhain RJEM, van der Heidenn A N, ter Haar NT, Breedveld FC, Miltenburg AMM. Shift toward T lymphocyte with a T helper 1 cytokine-secretion profile in the joints of patients with rheumatoid arthritis. Arthritis Rheum 1996; 39:1961-9.

16 Schulze-Koops H, Lipsky PE, Kavanaugh F, Davis LS. Elevated Th1- or Th0-like cytokine mRNA in peripheral circulation of patients whith rheumatoid arthritis. Modulation by treatment with anti-ICAM-1 correlates with clinical benefit. J Immunol 1995;155:5029-37.

17 Simon AK, Seipelt E, Sieper J. Divergent T-cell cytokine patterns in inflammatory arthritis. Proc Natl Acad Sci USA 1994;91:8562-6.

18 Ying Z, Neure L, Grolms M, Eggens U, Radbruch A, Braun $\mathrm{J}$, et al. Th1/Th2 cytokine patterns in the joint of rheumatoid arthritis and reactive arthritis patients: analysis at the single cell level. Arthritis Rheum 1997;40:S37

19 Smeets TJM, Dolhain RJEM, Miltenburg AMM, de Kuiper R, Breedveld FC, Tak PP. Poor expression of T-cell derived cytokines and activation and proliferation markers in early rheumatoid synovial tissue. Clin Immunol Immunopathol 1998;88:84-90

20 Schlaak J, Hermann E, Ringhoffer M, Probst P, Gallati H, Meyer KH, et al. Predominance of Th1-type T cells in synovial fluid of patients with Yersinia-induced reactive arthritis. Eur J Immunol 1992;22:2271-6.

21 Burmester GR, Daser A, Kamradt T, Krause A, Mitchison NA, Sieper J, et al. Immunology of reactive arthritides. Annu Rev Immunol 1996;13:229-50.

22 Smeets TJM, Dolhain REJM, Breedveld FC, Tak PP. Analysis of the cellular infiltrates and expression of Analysis of the cellular infiltrates and expression of arthritis and reactive arthritis. J Pathol 1998;186:75-81.
23 Gratacós J, Collado A, Filella X, Sanmartí R, Cañete JD, Llena J, et al. Serum cytokines (IL-6, TNF- $\alpha$, IL-1 $\beta$ and IFN- $\gamma$ ) in ankylosing spondylitis: a close correlation between serum IL-6 and disease activity and severity. Br J between serum IL-6 and diseas

24 Cañete JD, Llena J, Collado A, Sanmartí R, Gayá A, Gratacós J, et al. Comparative cytokine gene expression in synovial tissue of early rheumatoid arthritis and seronegative spondyloarthropathies. Br J Rheumatol 1997;36:38-42.

25 Kotake S, Schumacher HR Jr, Yarboro CH, Arayssi TK, Pando JA, Kanik KS, et al. In vivo gene expression of type 1 and type 2 cytokine in synovial tissues from patients in early stages of rheumatoid, reactive and undifferentiated

26 Braun J, Bollow M, Remlinger G, Eggens U, Rudwaleit M, Distler A, et al. Prevalence of spondyloarthropathies in HLA-B27 positive and negative blood donors. Arthritis Rheum 1998;41:58-67.

27 Lebman DA, Coffman RL. The effects of IL-4 and IL-5 on the IgA response by murine Peyer's patch B cell subpopulation. J Immunol 1988;141:2050-6.

28 Dougados M, van der Linden S, Juhlin R, Huitfeldt B, Amor B, Calin A, et al. The European Spondyloarthropathy Study Group preliminary criteria for the classification of spondyloarthropathy. Arthritis Rheum 1991;34:1218-27.

29 Thompson PW, Silman AJ, Kirwan SR, Currey HLF. Articular index of joint inflammation in rheumatoid arthritis. Correlation with the acute-phase response. Arthritis Rheum 1987;6:618-23.

30 Chomczynski P, Sacchi N. Single step method of RNA isolation by acid guanidium thiocyanate-phenol-chloroform extraction. Anal Biochem 1987;162:156-9.

31 Bucht A, Larsson P, Weisbrot L, Throne C, Pisa P, Smedegard G, et al. Expression of interferon-gamma (IFN- $\gamma$ ), LL-10, IL-12 and transforming growth factor-beta (TGF- $\beta$ ) mRNA in synovial fluid cells from patients in the early and late phases of rheumatoid arthritis (RA). Clin Exp Immunol 1996;103:357-67.

32 Mohler KM, Butler LD. Quantitation of cytokine mRNA levels utilizing the reverse transcriptase-polymerase chain reaction following primary antigen-specific sensitization in vivo. Verification of linearity, reproducibility and specificity. Mol Immunol 1991;28:437-47.

33 Ritchlin C, Haas-Smith SA, Hicks D, Cappucio J, Osterland CK, Looney J. Patterns of cytokine production in psoriatic synovium. J Rheumatol 1998;25:1544-52.

34 Steiner G, Tohidast-Akrad M, Witzmann G, Veseley M, Studnicka-Benke A, Gal A, et al. Cytokine production by synovial T-cells in rheumatoid arthritis. Rheumatology 1999;38:202-13.

35 Ulfgren A-K, Lindblad S, Klareskog L, Andersson J, Andersson U. Detection of cytokine producing cells in the synovial membrane from patients with rheumatoid arthritis. Ann Rheum Dis 1995;54:654-61.

36 Quayle AJ, Chomarat P, Miossec P, Kjeldsen-Kragh, Forre $\mathrm{O}$, Natvig JB. Rheumatoid inflammatory T-cell clones express mostly Th1 but also Th2 and mixed (Th0-like) cytokine pattern. Scand J Immunol 1993;38:75-82.

37 Dolhain RJEM, ter Harr NT, Hoefakker S, Tak PP, De Ley $\mathrm{M}$, Claassen E, et al. Increased expression of interferon (IFN)-gamma together with IFN-gamma receptor in the rheumatoid synovial membrane compared with synovium of patients with osteoarthritis. Br J Rheumatol 1996;35:24-32.

38 Nakamura T, Lee RK, Nam SY, Podack ER, Bottomly K, Flavell RA. Roles of IL- 4 and IFN- $\gamma$ in stabilizing the T helper cell type 1 and 2 phenotype. J Immunol 1997;158: 2648-53.

39 Simon AK, Seipelt E, Wu P, Wenzel B, Braun J, Sieper J. Analysis of cytokine profiles in synovial $\mathrm{T}$ cell clones from chlamydial reactive arthritis patients: predominance of Th1 subset. Clin Exp Immunol 1993;94:122-6.

40 Yin Z, Braun J, Neure L, Wu P, Liu L, Eggens U, et al. Crucial role of interleukin-10/interleukin-12 balance in the regulation of the type $2 \mathrm{~T}$ helper cytokine response in reacive arthritis. Arthritis Rheum 1997;40:1788-97.

41 van Roon JAG, Verhoef CM, van Roy JALM, GmeligMeyling FHJ, Huber-Bruning O, Lafeber FPJG, et al. Decrease in peripheral type 1 over type $2 \mathrm{~T}$ cell cytokine production in patients with rheumatoid arthritis correlates with an increase in severity of disease. Ann Rheum Dis 1997;56:656-60.

42 Brennan FM. Interleukin-10 and arthritis. Rheumatology 1999;38:293-7.

43 Müller B, Gimsa U, Mitchison A, Radbruch A, Sieper J, Yin Z. Modulating the Th1/Th2 balance in inflammatory arthritis. Springer Semin Immunopathol 1998;20:181-96.

44 Feldmann M, Brennan FM, Maini RN. Role of cytokines in rheumatoid arthritis. Annu Rev Immunol 1996;14:397-440.

45 Wang F, Sengupta TK, Zhong Z, Ivashkiv LB. Regulation of the balance of cytokine production and the signal transducer and activator of transcription (STAT) factor Med 1995;182:1825-31. 